\title{
An educational program using Driver Model and its effect on skill and planning performance Level of the field hockey beginner
}

\section{"Dr/ Shimaa Maher Ahmed Mohamed}

The presentation and research problem:

Driver Model is as the other models that emerged from constructive philosophy based on the learner inter pretation of the phenomena and to be able to absorb them according to past experience, this model returned the learner to the point of origin to measure his individual ability to interpret arrange of concepts and how to develop or deny it, and trying to link it to apredefined concept by the learner, so that the problems of changing perceptions is overcome by the learner's previous experience. (4: 31,32) The" researcher" noticed from apersonal interview with one of Eastern club coaches at Zakazik governerate, there is some difficulties at field hockey beginner during his training for offensive and defensive tactics and distraction because of linking between physical, skill and planning side, some need physical side and the other needs mental side which lead to thonghts distraction. So, the researcher saw that Driver model is one of recent strategies in the teaching of science which contributes to the development of thinking in its various forms, modes and types of teaching and learning basing on several steps or stages( guidance, showing thoughts, reformulating ideas, applying ideas, revising changing in ideas), all these steps contributes to the development of introspection and observation, uncovering mistakes, reaching conclusions, providing convincing explanations and developing to motivating learners to learn and research and unveil new attitudes. So, the researcher built a learning program using Driver model and field hockey beginner.

\section{The research objective:}

The research aims to build an educational program using Driver model and its

Lecturer curriculum department and teaching physical education (field hockey) at the faculty of physical Education Assuit University. 


\section{5}

impact on the skill and planning level performance of the field hockey beginner.

The research hypothesis:

1- There are statistically significant differences between pre- and post measurements scores for the trial group (under research) at a skilled performance level of field hockey beginner for post measurement.

2- There are statistically significant differences between pre- and post measurements scores for the trial group (under research) at a planning performance level of field hockey starter for post measurement.

3- There's a statistically corre lation between skill and planning performance level of field hockey beginner.

The research procedures and plan:
- The research method: the researcher used the trial method using the pre- and post measurements for one trial group, suitable for the nature of the research.

The research community: the research community represents young field hockey at Alsharqeya governorate and their numbers are(75) starter at(3) clubs and they are (25) starters at Eastern sport club- (25) starters at al- Sadat youth center club-(25) starters at Dayrab Negm sport club for sportive season 2019/2020.

The research sample: the sample was selected randomly from Eastern sport club(25) starter girls bornin (20042005) under (16 years), (20) of them are basic sample and (5) of them are goal keepers. (11) starter girls has been chosen from Al- Sadat youth center club as an exploratory sample.

Table (1)

The research community and sample description

\begin{tabular}{c|c|c|c|c|c|c|c}
\hline \hline No & $\begin{array}{c}\text { original } \\
\text { community }\end{array}$ & $\begin{array}{c}\text { sample percentage } \\
\text { from Original } \\
\text { community }\end{array}$ & \multicolumn{2}{|c|}{ basic sample } & \multicolumn{2}{|c}{$\begin{array}{c}\text { exploratory } \\
\text { sample }\end{array}$} \\
\cline { 3 - 8 } & No & $\begin{array}{c}\text { percentage } \\
\text { Percentile }\end{array}$ & no & $\begin{array}{c}\text { Percentage } \\
\text { Percentile }\end{array}$ & no & $\begin{array}{c}\text { percentage } \\
\text { Percentile }\end{array}$ \\
\hline \hline 1 & 75 & 25 & $33.34 \%$ & 20 & $26.67 \%$ & 11 & $14.67 \%$ \\
\hline \hline
\end{tabular}

The research sample homogeneity: The researcher

processed research sample homogeneity at these growth variables (age- lengthweight), and compound

physical and skill variable, and offensive and defensive planning under research. Tables $(2,3,4,5)$ indicate that. 


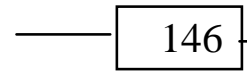

\section{Table (2) \\ Arithmetical mean, standard deviation, moderator, spawning and flattening factors for research sample at growth variables $(\mathbf{n}=31)$}

\begin{tabular}{c|c|c|c|c|c|c|c}
\hline \hline no & variables & $\begin{array}{c}\text { Measuring } \\
\text { unit }\end{array}$ & $\begin{array}{c}\text { Arithmetical } \\
\text { mean }\end{array}$ & $\begin{array}{c}\text { Standard } \\
\text { deviation }\end{array}$ & moderator & $\begin{array}{c}\text { Spawning } \\
\text { factor }\end{array}$ & $\begin{array}{c}\text { Flattening } \\
\text { Factor }\end{array}$ \\
\hline \hline 1 & Age & Year & 15.54 & 0.50 & 16 & -0.20 & -2.09 \\
\hline 2 & Length & $\mathrm{cm}$. & 166.95 & 3.279 & 167 & -0.180 & -0.75 \\
\hline 3 & weight & Kg. & 61.08 & 5.64 & 63.6 & -0.55 & -0.17 \\
\hline \hline
\end{tabular}

Table (2) indicates the arithmetical mean, standard deviation, spawning factor value and flattening factor for research sample at growth variables (age- length- weight) where spawning factor values are between (3+) which indicates the moderation and homogeneity of the sample

distribution in these variables,

\section{Table (3)}

Arithmetical mean, standard deviation, moderator, spawning and under research $(\mathrm{No}=31)$

\begin{tabular}{|c|c|c|c|c|c|c|c|c|}
\hline No & \multicolumn{2}{|c|}{$\begin{array}{l}\text { Physical } \\
\text { Variables }\end{array}$} & $\begin{array}{l}\text { Measuring } \\
\text { unit }\end{array}$ & $\begin{array}{c}\text { Arithmetical } \\
\text { mean }\end{array}$ & $\begin{array}{l}\text { standard } \\
\text { deviation }\end{array}$ & moderator & $\begin{array}{l}\text { Spawning } \\
\text { factor }\end{array}$ & flattening \\
\hline \multirow[t]{2}{*}{1} & \multirow{2}{*}{$\begin{array}{c}\text { Fist } \\
\text { power } \\
\text { test } \\
\end{array}$} & right & $\mathrm{Kg}$ & 22.41 & 2.54 & 20 & 0.06 & -2.13 \\
\hline & & left & $\mathrm{Kg}$ & 22.09 & 2.57 & 20 & 0.18 & -1.86 \\
\hline 2 & \multicolumn{2}{|l|}{$\begin{array}{c}\text { Motor } \\
\text { speed } \\
\text { test } \\
\end{array}$} & Degree & 6.32 & 1.04 & 6 & -0.14 & -0.54 \\
\hline 3 & \multicolumn{2}{|c|}{$\begin{array}{l}\text { Test to bend } \\
\text { the torso } \\
\text { forward from } \\
\text { standing }\end{array}$} & $\mathrm{Cm}$ & 18.29 & 2.23 & 18 & -0.16 & -1.12 \\
\hline 4 & \multicolumn{2}{|c|}{ Shuttle test } & Second & 10.61 & 0.66 & 11 & 0.63 & -0.54 \\
\hline 5 & \multicolumn{2}{|c|}{$\begin{array}{l}\text { Wide bounce } \\
\text { test of stability }\end{array}$} & Meter & 162.48 & 16.29 & 165 & -0.69 & 0.54 \\
\hline 6 & \multicolumn{2}{|c|}{$\begin{array}{c}\text { Batting teston } \\
\text { over lapping } \\
\text { rectangles }\end{array}$} & Number & 2.48 & 0.56 & 3 & -0.51 & -0.71 \\
\hline
\end{tabular}

and values of flattening factors of research sample should be less than (3) until the factor gets flattened which indicates moderation of sample distribution. The researcher performed a sample homogeneity test of physical, skill and planning variables, table (3) shows that.

\section{flattening factors for research sample of some physical variables} Arihnetion 
Follow Table (3)

Arithmetical mean, standard deviation, moderator, spawning and flattening factors for research sample of some physical variables under research $(\mathrm{No}=31)$

\begin{tabular}{|c|c|c|c|c|c|c|c|}
\hline No & $\begin{array}{c}\text { Physical } \\
\text { Variables }\end{array}$ & $\begin{array}{c}\text { Measuring } \\
\text { unit }\end{array}$ & $\begin{array}{c}\text { Arithmetical } \\
\text { mean }\end{array}$ & $\begin{array}{l}\text { standard } \\
\text { deviation }\end{array}$ & moderator & $\begin{array}{c}\text { Spawning } \\
\text { factor }\end{array}$ & flattening \\
\hline & $\begin{array}{c}\text { Compound } \\
\text { skill variables }\end{array}$ & & & & & & \\
\hline \multirow{2}{*}{1} & \multirow{2}{*}{$\begin{array}{l}\text { Reseiving and } \\
\text { passing ball } \\
\text { with flat face }\end{array}$} & Second & 5.14 & 1.41 & 5 & 1.11 & 0.94 \\
\hline & & Degree & 5.25 & 0.96 & 5 & -0.79 & 0.22 \\
\hline \multirow[b]{2}{*}{2} & \multirow{2}{*}{$\begin{array}{l}\text { Reseiving, } \\
\text { rolling then } \\
\text { passing with } \\
\text { flat face }\end{array}$} & Second & 8.86 & 1.05 & 8.44 & 1.17 & 2.36 \\
\hline & & Degree & 5.45 & 1.15 & 6 & -0.01 & -1.43 \\
\hline \multirow[b]{2}{*}{3} & \multirow{2}{*}{$\begin{array}{l}\text { Reseiving, } \\
\text { rolling, } \\
\text { twirling, } \\
\text { passing with } \\
\text { flat face }\end{array}$} & Second & 13.27 & 1.04 & 13.44 & -1.30 & 1.91 \\
\hline & & Degree & 5.67 & 1.01 & 6 & -0.31 & -0.90 \\
\hline \multirow[b]{2}{*}{4} & \multirow{2}{*}{$\begin{array}{l}\text { Reseiving, } \\
\text { twirling, } \\
\text { passing with } \\
\text { flat face }\end{array}$} & Second & 12.31 & 1.07 & 12.2 & -0.10 & -0.52 \\
\hline & & Degree & 6.19 & 0.98 & 6 & 0.49 & -0.61 \\
\hline \multirow{2}{*}{5} & \multirow{2}{*}{$\begin{array}{l}\text { Direct passing } \\
\text { with flat face }\end{array}$} & Second & 3.12 & 0.76 & 3 & 0.72 & 0.86 \\
\hline & & Degree & 6.64 & 1.58 & 8 & -0.66 & -1.05 \\
\hline \multirow{3}{*}{6} & \multirow{2}{*}{$\begin{array}{l}\text { Direct aim with } \\
\text { flat face }\end{array}$} & Second & 3.16 & 0.67 & 8 & -0.22 & -0.50 \\
\hline & & Degree & 7.41 & 1.23 & 8 & -0.54 & -0.53 \\
\hline & $\begin{array}{l}\text { Defensive plan } \\
\text { variables }\end{array}$ & & & & & & \\
\hline 1 & $\begin{array}{l}\text { Depth in } \\
\text { defense }\end{array}$ & Degree & 1.38 & 0.66 & 1 & 1.52 & 1.12 \\
\hline 2 & $\begin{array}{l}\text { Delayed in } \\
\text { defense }\end{array}$ & Degree & 1.64 & 0.87 & 1 & 0.78 & -1.24 \\
\hline \multirow[t]{2}{*}{3} & $\begin{array}{c}\text { Balanced in } \\
\text { defense }\end{array}$ & Degree & 1.32 & 0.59 & 1 & 1.74 & 2.15 \\
\hline & $\begin{array}{l}\text { Offensive plan } \\
\text { variables }\end{array}$ & & & & & & \\
\hline 1 & Direct playing & Degree & 1.70 & 0.82 & 1 & 0.60 & -1.25 \\
\hline 2 & $\begin{array}{c}\text { Follow - on } \\
\text { attack }\end{array}$ & Degree & 1.58 & 0.50 & 2 & -0.34 & -2.01 \\
\hline 3 & $\begin{array}{c}\text { Increase in } \\
\text { number of } \\
\text { attacks }\end{array}$ & Degree & 1.48 & 0.76 & 1 & 1.23 & -0.07 \\
\hline & \multicolumn{3}{|c|}{$\begin{array}{l}\text { Table (3) shows } \\
\text { arithmetical mean, standard } \\
\text { deviation and value of } \\
\text { spawning and flattening factors } \\
\text { of research sample of the } \\
\text { physical variables, compound }\end{array}$} & \multicolumn{4}{|c|}{$\begin{array}{l}\text { skill variables and planning } \\
\text { variables under research, where } \\
\text { we can see that spawning } \\
\text { factor values are between }(3+) \\
\text { which indicates the moderation } \\
\text { of sample distribution and }\end{array}$} \\
\hline
\end{tabular}


homogeneity at these variable, and flattening factor values of research sample should be less than (3) to get a flatten factor which indicates moderation of sample distribution .

\section{Data collecting tools:}

1- Experts survey from to determine the most appropriate physical test for the skills under research.

2- Experts survey from to determine the most appropriate skill tests of compound motor performance for skills under research.

3- Experts survey from to determine the most appropriate planning tests (defensive and offensive) for skills under research.

First exploratory study: It has been done from (1/ 10/ 2018) to $(3 / 10 / 2018)$ to find scientif factors (honest- stability) of physical tests, compound skills and planning .

Second exploratory study: It has been done from $(3 / 10$ /2018) to $(4 / 10 / 2018)$ to try some lessons from the proposed tutorial to determine the extent to which the lessons could be applied and to ensure that Driver's model was used in the application procedures and the tools needed for the application, and the study achieved its targets .
Procedures for implementing the proposed educational program:

The Pre-measurement:The Pre-measurement of Variables under research for trial group implemented from (13/ 10/ 2018) to (15/ 10/ 2018) for basic sample under research.

\section{Implementation}

and application of the proposed educational program:

The program Implemented by using Driver model to improve skill and planning performance level of field hockey starter (trial group) it takes (4) weeks, three lessons a week because the Eastern club training was at (Saturday-

MondayWednesday) and it is Implemented from Wednesday (17/ 10/ 2018) till Saturday (17/ 11/ 2018) so, it has been teached (3) lesson a week, and the supposed educational program was of (4) educational units at (12) lesson, with time (90) minutes attach (10).

The post - measurement :The post - measurement of trial groups for skills under research at the same arrangement and conditions of Premeasurements from (19/11/ 2018) to (21/ 11/ 2018).

The used statistic process: Arithmetical mean - standard deviation- moderator- spawning 
factor- correlation factorflattening factor - improvement percentage - test equation.( $\mathrm{T}$ ) Presentation and discussion of results:There are statistical differences between average

\section{Table (4)}

Significance of differences between pre and post measurements averages, value of $(T)$ and improvement rate of trial group at skill tests (under research) $($ No $=20)$

\begin{tabular}{|c|c|c|c|c|c|c|c|c|c|}
\hline \multirow{2}{*}{ No } & \multirow{2}{*}{$\begin{array}{c}\text { Skill tests } \\
\text { (compound } \\
\text { motor } \\
\text { performances) }\end{array}$} & \multirow{2}{*}{$\begin{array}{c}\text { Measuring } \\
\text { unit }\end{array}$} & \multicolumn{2}{|c|}{$\begin{array}{c}\text { Pre- } \\
\text { measurement }\end{array}$} & \multicolumn{2}{|c|}{$\begin{array}{c}\text { post- } \\
\text { measurement }\end{array}$} & \multirow{2}{*}{$\begin{array}{l}\text { Value } \\
\text { of(T) }\end{array}$} & \multirow{2}{*}{$\begin{array}{l}\text { Difference } \\
\text { between } \\
\text { averages }\end{array}$} & \multirow{2}{*}{$\begin{array}{c}\text { Improving } \\
\text { rate }\end{array}$} \\
\hline & & & $\mathbf{M}$ & $\mathbf{S}$ & $\mathbf{M}$ & $\mathbf{S}$ & & & \\
\hline \multirow[t]{2}{*}{1} & \multirow{2}{*}{$\begin{array}{l}\text { Receiving and } \\
\text { passing ball } \\
\text { with flat face }\end{array}$} & Second & 4.50 & 0.89 & 3.32 & 0.60 & 5.93 & 1.18 & $\% 35.55$ \\
\hline & & Degree & 5.25 & 1.16 & 9.15 & 0.58 & 3.65 & 3.9 & $\% 74.29$ \\
\hline \multirow[t]{2}{*}{2} & \multirow{2}{*}{$\begin{array}{l}\text { Receiving, } \\
\text { rolling and } \\
\text { passing ball } \\
\text { with flat face }\end{array}$} & Second & 8.59 & 0.79 & 7.14 & 1.13 & 7.36 & 1.45 & $\% 20.31$ \\
\hline & & Degree & 5.75 & 1.20 & 9.25 & 0.71 & 8.69 & 3.5 & $\% 60.87$ \\
\hline \multirow[t]{2}{*}{3} & \multirow{2}{*}{$\begin{array}{c}\text { Receiving, } \\
\text { rolling, twirling } \\
\text {,passing with flat } \\
\text { face }\end{array}$} & Second & 13.03 & 1.14 & 12.11 & 1.17 & 7.14 & .92 & $\% 7.60$ \\
\hline & & Degree & 6.30 & 0.57 & 8.85 & 0.58 & 8.99 & 2.55 & $\% 40.48$ \\
\hline \multirow[t]{2}{*}{4} & \multirow{2}{*}{$\begin{array}{c}\text { Receiving, } \\
\text { twirling, passing, } \\
\text { with flat face }\end{array}$} & Second & 12.13 & 1.15 & 11.08 & 1.41 & 5.95 & 1.05 & $\% 9.48$ \\
\hline & & Degree & 6.65 & 0.87 & 8.75 & 0.63 & 8.54 & 2.1 & $\% 31.58$ \\
\hline \multirow[t]{2}{*}{5} & \multirow{2}{*}{$\begin{array}{l}\text { Direct, passing, } \\
\text { with flat face } \\
\end{array}$} & Second & 3.20 & 0.88 & 2.20 & 0.89 & 9.56 & 1 & $\% 45.46$ \\
\hline & & Degree & 7.10 & 1.44 & 9.10 & 0.55 & 3.23 & 2 & $\% 28.17$ \\
\hline \multirow[t]{2}{*}{6} & \multirow{2}{*}{$\begin{array}{c}\text { Direct aim } \\
\text { with flat face }\end{array}$} & Second & 3.06 & 0.76 & 2.15 & 0.30 & 5.29 & .91 & $\% 42.33$ \\
\hline & & Degree & 6.85 & 1.18 & 8.95 & 0.68 & 8.19 & 2.1 & $\% 30.66$ \\
\hline
\end{tabular}

The value of $(\mathrm{T})$ at level $(0.05)=2.09$

From table (4) results, there are statistically differences between pre- and post measurements of trial group at skill performance level (compound motor scores of pre and post measurements for trial group (under research) at skill performance Level of field hockey starter for postmeasurement. 
and post measurements of trial group is between $(7.60 \%$ : $74.29 \%$ ) and this because of the educational program by using Driver model and its impacton skill level and what it involves from motor activities, difference and various applicable exercises and its organized, sequential steps that attract players attention, where the improving level is obvionsly clear, it is less in time tests and more in the other tests at post measurements of trial group at skill tests (compound motor performances).

"The researcher" suggests that the differences between pre- and post measurements of trial groupin all compound motor performance under research are due to the positive effect of the proposed educational program and the exercises it includes, the variety of ways in which they are performed and the nature of their execution where the focus was on kinetic speed with accuracy, also following various scientific methods used in the tutoring and training courses in situations similar to the one held in the games through the multiple player's positions. As a result these compound motor performances improved. The supposed educational program also helped by using Driver model to acquire the research sample aset of technical requirements for a distinctive game that helps to improve its aspects.

This agree with "Hussien Atif Hafez" (2003) study that field hockey sport is one off the sports which is characterized by rapid movement from defense to attack and vice versa so it requires physical, skill and planning preparation, so the player has the ability to behave in different situations in the game, so in order to reach the ideal level of planning preparation it depends on complementarity and consistency of other aspects of physical, skill and psychological preparation to excute the defensive and offensive player plans and individual one at the highest level to achieve best results. (3: 20)

There are statistically differences between pre- and post measurements of trial group (under research) at planning level performance of field hockey starter for post measurement. 
Table (5)

The significant differences between pre - and post measurements, the value of $(T)$ and improving rate of trial group at planning tests (under research) $(\mathrm{N}=\mathbf{2 0})$

\begin{tabular}{|c|c|c|c|c|c|c|c|c|c|}
\hline \multirow[t]{2}{*}{ No } & \multirow{2}{*}{$\begin{array}{r}\text { Planning } \\
\text { testes }\end{array}$} & \multirow{2}{*}{$\begin{array}{c}\text { Measuring } \\
\text { unit }\end{array}$} & \multicolumn{2}{|c|}{$\begin{array}{c}\text { Pre- } \\
\text { measurement }\end{array}$} & \multicolumn{2}{|c|}{$\begin{array}{c}\text { post- } \\
\text { measurement }\end{array}$} & \multirow{2}{*}{$\begin{array}{l}\text { Value } \\
\text { of(T) }\end{array}$} & \multirow{2}{*}{$\begin{array}{c}\text { Difference } \\
\text { between } \\
\text { averages }\end{array}$} & \multirow{2}{*}{$\begin{array}{l}\text { Improving } \\
\text { rate }\end{array}$} \\
\hline & & & M & $\mathbf{S}$ & M & $\mathbf{S}$ & & & \\
\hline \multirow[t]{2}{*}{1} & $\begin{array}{l}\text { Defensive } \\
\text { plans }\end{array}$ & \multirow{2}{*}{ degree } & \multirow{2}{*}{0.62} & \multirow{2}{*}{0.21} & \multirow{2}{*}{2.25} & \multirow{2}{*}{0.85} & \multirow{2}{*}{6.63} & \multirow{2}{*}{1.63} & \multirow{2}{*}{$\% 262.91$} \\
\hline & $\begin{array}{l}\text { Depth in } \\
\text { defense }\end{array}$ & & & & & & & & \\
\hline 2 & $\begin{array}{l}\text { Delay in } \\
\text { defense }\end{array}$ & degree & 0.55 & 0.18 & 2.15 & 0.87 & 7.97 & 1.6 & $\% 290.91$ \\
\hline 3 & $\begin{array}{c}\text { Balanced } \\
\text { defense }\end{array}$ & degree & 0.57 & 0.35 & 1.95 & 0.75 & 9.67 & 1.38 & $\% 242.11$ \\
\hline \multirow[t]{2}{*}{1} & $\begin{array}{l}\text { Offensive } \\
\text { plans }\end{array}$ & \multirow{2}{*}{ degree } & \multirow{2}{*}{0.52} & \multirow{2}{*}{0.16} & \multirow{2}{*}{2.2} & \multirow{2}{*}{0.52} & \multirow{2}{*}{7.64} & \multirow{2}{*}{1.68} & \multirow{2}{*}{$\% 242.11$} \\
\hline & $\begin{array}{c}\text { Direct } \\
\text { playing }\end{array}$ & & & & & & & & \\
\hline 2 & $\begin{array}{l}\text { Follow- } \\
\text { on attack }\end{array}$ & degree & 0.79 & 0.26 & 2.45 & & 9.88 & 1.66 & $\% 210.13$ \\
\hline 3 & $\begin{array}{c}\text { Increase } \\
\text { in number } \\
\text { of attack }\end{array}$ & degree & 0.79 & 0.26 & 2.05 & 0.88 & 8.24 & 1.26 & $\% 159.50$ \\
\hline
\end{tabular}

The schedule value of $(\mathrm{T})$ at level $(0.05)=2.09$

From table (5) it is clear that are statistically differences between pre and post measurements of trial group at planning performance level (offensive and defensive plans) where the value of $(\mathrm{T})$ is between $(6.63: 9.88)$ which is more than the value of schedule (T) at level (0.05) it is clear from the table that improving rate between $(159.50 \%: 290.91 \%)$ and this because of the followed educational program by using Driver model and its impact on planning level and what it includes of offensive and defensive plans and competitive playing situation to attract players and develop their creative abilities with organized and sequential steps that attract player, where the improving rate is obviously clear at post measurement of trial group at planning tests (offensive and defensive) for skills under research.

"The researcher" sees that the differences between pre- and post measurement of trial group at all planning tests (defensive and offensive) under research refers to positive effect of supposed educational program by using Driver model 
and what it includes of technical training which similar to motor performance nature at hockey for (defensive offensive )plans, that convenient with games and competitions demands, also, the research takes care of gradient in difference playing situation and individual differences between the players and elastic in program application through varaity in chosen training, Thus the players achieve different offensive and defensive plans through games with amechanism and with effective and strong form.

This study agrees with the study results of "Abd Al-
Khaleq Esam Al-deen "(2005) (1), and study of "Zaki Mostafa Abd AlHamid"(2009) (5), and study of "Abo Abdo Hassan AlSayed" (2010) (2) where they emphasize the importance of defensive and offensive planning variables and planning preparation plays an essential role at games results because it represents the form of team performance through games, and it is one of the most important factors of performance success in group sports. There is some relation statistically significant between planning and skill performance level at field hockey.

Table (6)

Correlation matrix between planning and skill performance at field hockey beginner $(n=20)$

\begin{tabular}{|c|c|c|c|c|c|c|c|}
\hline $\begin{array}{l}\text { Planning } \\
\text { performace } \\
\text { Skill } \\
\text { performance }\end{array}$ & $\begin{array}{c}\text { Measuring } \\
\text { unit }\end{array}$ & $\begin{array}{l}\text { Depthin } \\
\text { defeuse }\end{array}$ & $\begin{array}{l}\text { Delayin } \\
\text { defeuse }\end{array}$ & $\begin{array}{c}\text { Balanced } \\
\text { defense }\end{array}$ & $\begin{array}{c}\text { Direct } \\
\text { playing }\end{array}$ & $\begin{array}{l}\text { Follow- } \\
\text { on } \\
\text { atlack }\end{array}$ & $\begin{array}{c}\text { Increasing } \\
\text { number at } \\
\text { attack }\end{array}$ \\
\hline \multirow{2}{*}{$\begin{array}{l}\text { Receiving, passing } \\
\text { ball with flat face }\end{array}$} & Second & 0.540 & 0.582 & 0.659 & 0.579 & 0.523 & 0.576 \\
\hline & Degree & 0.530 & 0.736 & 0.539 & 0.532 & 0.634 & 0.564 \\
\hline \multirow{2}{*}{$\begin{array}{l}\text { Receiving ,rolling, } \\
\text { passing ball with } \\
\text { flat face }\end{array}$} & Second & 0.501 & 0.730 & 0.625 & 0.502 & 0.577 & 0.578 \\
\hline & Degree & 0.510 & 0.587 & 0.519 & 0.505 & 0.515 & 0.726 \\
\hline \multirow{2}{*}{$\begin{array}{l}\text { Receiving, rolling } \\
\text {,twirling, passing } \\
\text { ball with flat face }\end{array}$} & Second & 0.534 & 0.607 & 0.615 & 0.544 & 0.654 & 0.608 \\
\hline & Degree & 0.600 & 0.626 & 0.608 & 0.534 & 0.608 & 0.634 \\
\hline \multirow{2}{*}{$\begin{array}{l}\text { Receiving } \\
\text {,twirling, passing } \\
\text { ball with flat face }\end{array}$} & Second & 0.541 & 0.572 & 0.860 & 0.518 & 0.518 & 0.548 \\
\hline & Degree & 0.517 & 0.741 & 0.601 & 0.548 & 0.577 & 0.517 \\
\hline \multirow{2}{*}{$\begin{array}{l}\text { Direct passing } \\
\text { with flat face }\end{array}$} & Second & 0.588 & 0.561 & 0.636 & 0.615 & 0.545 & 0.566 \\
\hline & Degree & 0.563 & 0.541 & 0.596 & 0.520 & 0.550 & 0.549 \\
\hline \multirow{2}{*}{$\begin{array}{l}\text { Direct aiming } \\
\text { with flat face }\end{array}$} & Second & 0.553 & 0.614 & 0.528 & 0.523 & 0.641 & 0.527 \\
\hline & Degree & 0.545 & 0.777 & 0.624 & 0.522 & 0.641 & 0.719 \\
\hline
\end{tabular}

The value of schedule $(\mathrm{R})$ at level $(0.05)=0.433$ 
From table (6) there is an exorcism correlation statistically significant at skill performance level (compound motor performances) and planning performance level (offensive and defensive plans) where the calculated value of "R" is between (0.501: 0.860) and it is more than the schedule value of " $\mathrm{R}$ " at significant levd (0.05).

The research finds from the previous table an exorcism correlation statistically significant between compound motor skill which is receiving then passing with flat face and between defensive planning variable which is balance in defense because it is a higher correlation value. So, it shows that when applying planning variables there should be a varaity in basic motor skills compatible with methods and planning playing situation and helding competitive games to change offensive and defensive playing plans, and developing basic compound motor skills.

This result agrees with "Zaki Mostafa Abd El- Hamid" (2009) that planning work (defensive and offensive) from the most important performance success factors in team sports, where planning understanding and the ability to be have according to different situation in team sports is achieving excellency and accomplishment through competition. (5: 33)

\section{Conclusion:}

1- Applying an educational program using Driver model lead to improving planning and skill performance level of the field hockey beginner.

2- The stages of Driver model help the beginners developing their level and make them active participant within the educational lesson.

\section{Recommendations:}

1- Using modern and developed educational models at building and designing educational programs to promote with physical, skill and planning levels for field hockey beginners.

2- The essentiality of using the educational proposed program in the hockey Egyptian union and clubs to get benefit from it and reach with the beginners to highest levels of champions.

\section{Refernces:}

1- Abd El-Khalik Esam AlDeen: Sportive Training Theories and Applications, p. 4 Monshat Almaaref, Alexandria, 2005.

2- Abo Abdo Hassan AlSayed: Modern methods of Trends in Planning and training 
football, p.10, Artistic beams Library, Alexandria, 2010.

3- Hussien Atef Hafez: Developing planning Aspects for Field Hockey beginners at Al-Sharqeya Governorate, $\mathrm{Ph}$.D letter, faculty of Physical Education for Boys, AlZakazik University, 2003.

4- Zaki Hanan Mostafa: The effect of using a supposed program based on Driver model at modifying some modernized biological concepts and developing critical thinking and moral and biological values for Faculty of Education students, Scientific Education magazine, folder, number (3), 2013.

5- Zaki Mustafa Abd ElHamid: Effective Longitudinal and modular Training at Developing Physical and Technical Abilities for Defensive Centers Players at Football, Physical Education Researchs magazine, 78 number, faculty of Physical Education for Boys, Zakazik University, 2009. 